\title{
Green Concept within Public Corridor Rearrangement and Sustainability: Case Study of Mayjen Yono Suwoyo Street, Surabaya, Indonesia
}

\author{
Sotya Pawestri ${ }^{1}$, Bambang Soemardiono ${ }^{2} \&$ Ima Defiana $^{3}$ \\ ${ }^{1}$ Postgraduates Student, Department of Architecture, Faculty of Architecture, Design and Planning, Sepuluh \\ Nopember Institute of Technology, Surabaya, East Jawa, Indonesia \\ ${ }^{2-3}$ Lecturer, Department of Architecture, Faculty of Architecture, Design and Planning, Sepuluh Nopember \\ Institute of Technology, Surabaya, East Jawa, Indonesia
}

\begin{abstract}
Public green open space is a critical component that affects the quality of human life, both ecologically and sociallypsychologically. Surabaya, a metropolitan city in Indonesia, is currently trying to meet the needs of public green open spaces. In the commercial area, the social needs of the Surabaya community towards their environment prove that commercial corridors require sustainable green open space arrangement, where socially sustainable can overcome the saturation in economic activities and also can improve environmental conditions. The method in this study uses case study research methods, synopsis, and incremental design methods. The method requires a systematic approach to the existing conditions of the corridor from the existing cases- preparation of criteria and the concept of sustainable public green open space complement the method. The results of the study are structuring urban space in social activities to reduce the saturation of commercial actors, such as by adding a seating area for relaxation for the community, a play area for recreation and an education area in the area around the pond. This result is following the representation of the criteria and concepts of research and structuring of public green open space, which proves that emphasizing social activities can apply sustainability to the study area. The arrangement is carried out in the median, road roundabout and other elements in the commercial corridor of Mayjen Yono Suwoyo according to several factors and structuring criteria.
\end{abstract}

Key Words: Public Space, Green Area, Sustainable, Urban Landscape.

\section{INTRODUCTION}

The city structure is made up of buildings, urban roads, and green open spaces. The importance of the existence of the city's green open space has been proven in several studies [1] where the city's green open space is a critical component that affects the quality of human life, both ecologically and socially-psychologically. However, the proportion is currently decreasing as a result of the high population density due to the increasing growth of the human population. In its development, green open space is used as a public space that fits the needs of the social life of urban residents. The social needs in question are activities that gather together and create an atmosphere of relaxation. In the study [2] explained that city residents living in green urban areas showed lower symptoms of anxiety or depression than residents living in densely populated areas such as metropolitan cities.

Surabaya is the second largest metropolitan city in Indonesia and is the center of government, business, trade, industry, and education in East Java Province. Surabaya has an area of around $350.54 \mathrm{~km}^{2}$ with a reasonably high population density of $5,000,000$. One part of Surabaya, which is a supporter of trade, tourism, and education is the area of West Surabaya. Since 2004, population density in Surabaya has also affected the existence of public green open spaces so that the Surabaya government revives the function of green open spaces in several regions. West Surabaya region is a growth area of modern life with the presence of apartments and luxury housing. Also, this region has educational facilities such as Surabaya State University, Ciputra University, and trade facilities for both small, medium, and large private businesses whose development is more concerned with lifestyle tourism. The area has many facilities and buildings that display an independent city. Therefore, West Surabaya is the majority area for residential areas and commercial areas that are growing rapidly and strategically.

The case study is in the Corridor of Mayjen Yono Suwoyo, which is part of the Pradah Kali Kendal Village, Dukuh Pakis District in the West Surabaya area. The reason for choosing the case study is because the condition of the location is a corridor with rapid and strategic commercial growth but does not yet have public space as an attraction by maximizing land constraints and 
sustainability which focuses more on social activities. Also, the corridor still requires an increase in aesthetic values. The location used as a study is $1 \mathrm{~km}$ long from the specified limit. Access in the Yono Suwoyo Corridor is $40.5 \mathrm{~m}$ from the fence to the fence with a median of 12 meters of road and a roundabout of 89 meters in diameter. Area boundaries for research are as follows:

$>$ West : Shops on Mayjen Yono Suwoyo St.

$>$ East : Shops on Mayjen Yono Suwoyo St., Lenmarc Mall and Puncak Bukit Golf Apartment

$>$ North : Node of HR Muhammad St.

$>$ South : Boulevard on Mayjend Suwoyo St.

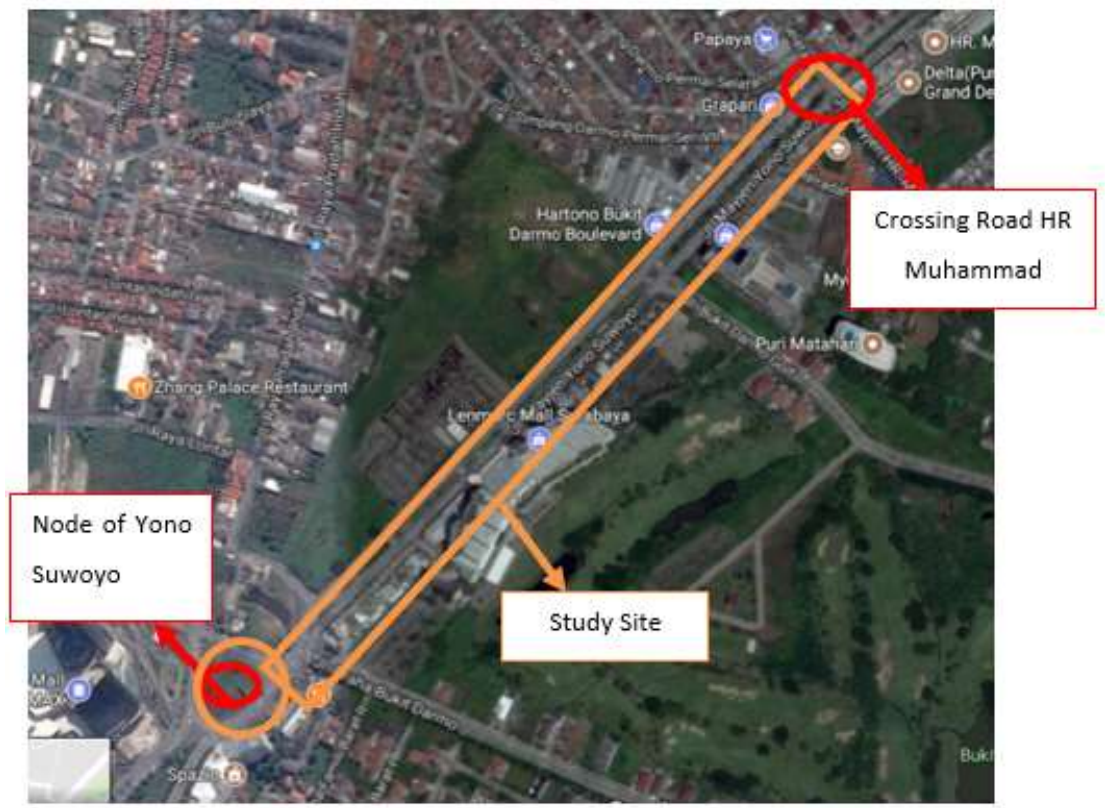

Figure 1.1: Corridor Map of Mayjen Yono Suwoyo

The purpose of this research is to arrange public green open space and its elements in the Corridor of Mayjen Yono Suwoyo Street based on criteria and concepts in order to increase social, economic, and environmental activities for surrounding communities and commercial actors in utilizing the median and road roundabouts.

\section{LITERATURE REVIEW}

In Reference [3], the development of sustainable city corridors included the use of limited land, energy and appropriate land conservation policies and cultural and social development embedded in the new city corridor design model. The stages of designing a sustainable city corridor, according to Reference [4] are:

$>$ Planning of the existing corridor together with agencies, the private sector, and residents to find out the potential and problems of the site

$>$ Transforming the corridor concept towards a more dynamic way to connect the main facilities and build services and parks that are more attractive to pedestrians

$>$ Improve economic access and social recreation, attract economic residents and social recreation, attract corridors to enjoy the sidewalks, roads, and systems offered

$>$ Develop environmental programs to improve community identity, provide natural resources, municipal services, and accommodate communities and support communities in improving the environment.

In Reference [5], in this case, adds the principle of sustainable relationships in people's lives (livability), namely:

- Give more transit transportation options such as shelter, walking area, and cycling for higher quality opportunities

- Increasing economic competitiveness

- Coordinating and improving government and private policies

- Support existing communities with recreational opportunities

- Social and community values 
Besides livability, sustainable city corridors are also supported by environmental designs that can interact with humans, namely biophilic design. Reference [6] explains the characteristics of biophilic designs as follows:

$>$ The biophilic design emphasizes human adaptation to the natural world

$>$ The biophilic design depends on repeated and continuous involvement with nature.

$>$ Biophilic design requires strengthening and integration of design interventions that are connected to the overall arrangement or space.

$>$ The biophilic design fosters emotional attachment to settings and place.

$>$ The biophilic design fosters interactions and positive and sustainable relationships between safety and the natural environment.

$>$ The effective biophilic design fosters relationships between people and their environment, enhances feelings of relationships, and a sense of membership in a meaningful community.

The synthesis of sustainable city corridor theory includes the deepening of the concept of sustainable city corridors. One of the strategies in developing development is taken into account the environment and energy and the social needs of urban communities. So that it can improve the economy and also comfort in the corridor that is in line with the needs of the city, this has been described by Reference [4] in the summary of the above theory. The strategy must include the principle of livability described by Reference [5]. For this reason, the biophilic concept that is capable of supporting environmental design to interact with humans needs to be used. The biophilic concept must also have the characteristics described by Reference [7] in order to realize interaction with nature.

\section{METHOD}

This research paradigm is naturalistic (a type of descriptive-explorative research) that uses case study research methods. The design method uses an incremental synopsis in the dominant and complementary design strategies (qualitative and quantitative) with qualitative analysis. The analysis includes aspects namely:

- Selection for Open Green Space and Social Needs

- Structuring The Compilation of Environmental Programs

- The Principle of Providing More Choices

- Relationship of Interaction between Elements

\section{RESULTS AND DISCUSSION}

The path of Mayjen Yono Suwoyo is a commercial corridor with high economic activity. Based on the Surabaya RDRTK data in 2017, the proportion between the built area on Mayjen Yono Suwoyo Street has been $70 \%$ (10\% in the development process) compared to $8 \%$ green open space, where green open space can be increased to public space to reduce saturation and meet needs society.

Based on the land use map, it can be seen that there is some potential around the open space that is the study area. There are different main components so that the arrangement of the corridor will later refer to predetermined zoning. The study area is divided into 3 (three) zones according to their functions.

$>$ Zone 1: General social activities, because it is close to residential apartments and luxury housing where the local community is a family occupying that particular residence.

$>$ Zone 2: Social activities to increase economic activities, because it is close to office, business and shopping centers where the majority of local communities are commercial actors such as workers and visitors who need services and goods in the area

$>$ Zone 3: Social activities to improve environmental conditions, this area is still close to a commercial area but also adjacent to a stalled area so that its presence can be increased to improve the area 


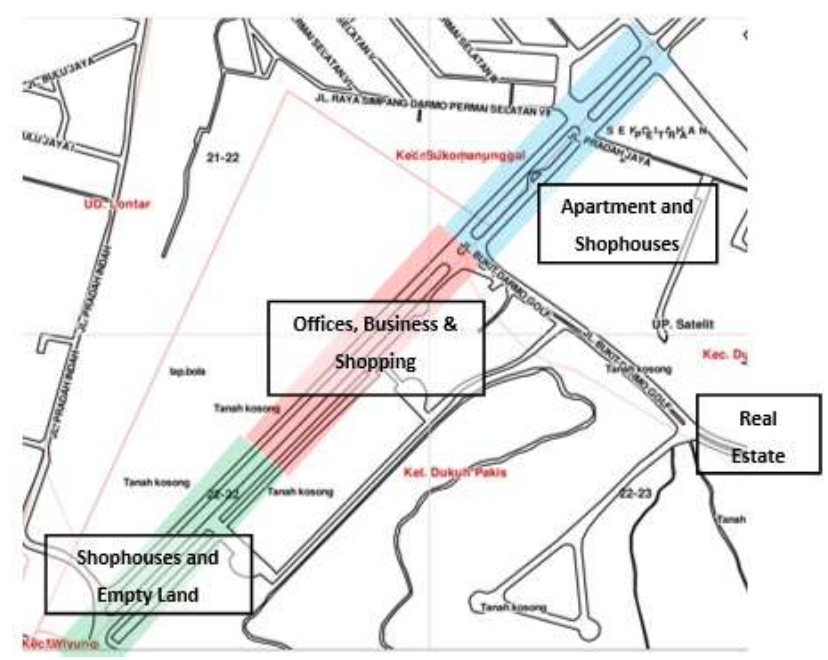

Figure 4.1: The Zones According to Their Functions

Factors of research in the form of structuring a sustainable public green space in a commercial corridor can be viewed from the sub-factors of a sustainable city corridor based on city corridor structuring requirements which must pay attention to vegetation and social activities. These factors are also supported by a review of the theory of Reference $[5,6]$ and the previous general criteria.

\subsection{Selection for Open Green Space and Social Needs}

In this study, sustainable city corridors must pay attention to the environment, namely by criteria for vegetation selection for open green space and energy and social needs. Also, based on interview data, the agency stated that the utilization of the median of the road as a public green space should be following the needs of the local community and be considered in more detail. From the above concept, it provides a relaxation area for commercial actors who experience saturation such as a relaxed seating area and provides an area as an attraction for commercial corridors such as an aesthetically photographed area to improve aesthetic, environmental conditions and utilization of renewable energy for the development of their environment. This matter is also supported by the single directional view analysis technique; this area is entirely lacking in providing road furniture so that the environment looks aesthetically pleasing. This corridor only has the attraction of sculpture elephants according to the theme of the shopping center. Besides, based on data from interviewing commercial actors and residents, this location is less exciting and saturating. Based on the criteria, the concepts and descriptions of the analysis techniques above are carried out:

$>$ Arrange a comfortable sitting area, and some are added with a table. Charger center with solar energy and shelter to enjoy the atmosphere while eating

$>$ Arranging sculpture with the theme of abstract commercial actors and using used iron materials and beautified in gray and cream.
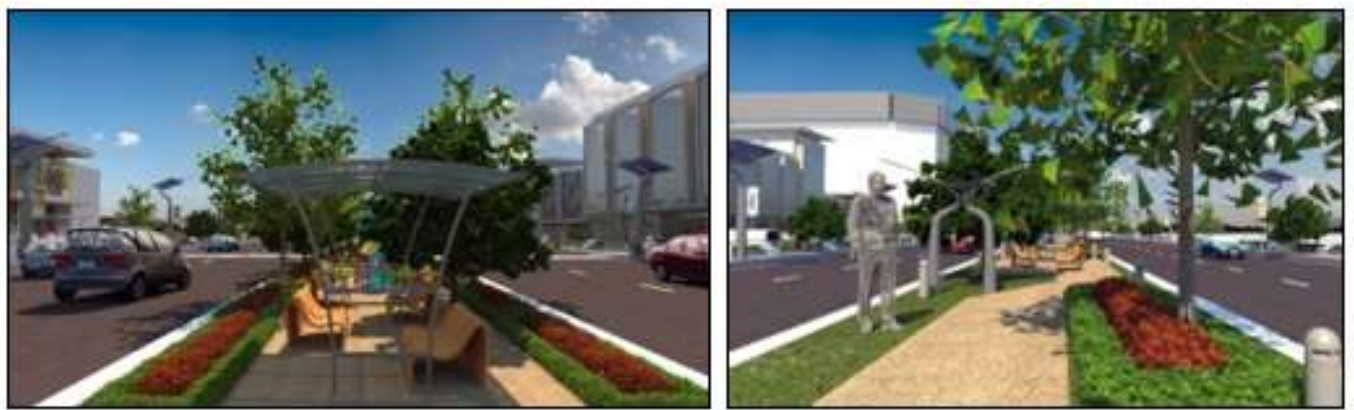

Figure 4.2: Arrangement of Sitting Area, Shelter, and Sculpture in Mayjen Yono Suwoyo Street Corridor

\subsection{Structuring The Compilation of Environmental Programs}

In this study, the requirements for designing a sustainable city corridor that must be fulfilled are structuring the compilation of environmental programs by transforming the concept of the corridor towards a more active, improving economic access and social recreation. Also, it is also following previous research studies where the need for increased vegetation in the city needs to be done to increase the quality of life. From the concept formulated: 
$>$ The existence of vacant land in this corridor can be used as a parking area so that there are no vehicles parked on the road or sidewalk.

$>$ Zone 1, adding facilities to the play area and jogging track for families.

$>$ Zone 2, adding a sitting area for relaxation with artificial shade and not and adding sculpture as an attraction.

$>$ Zone 3, adding relaxation areas such as sitting areas, sculptures and environmental education related to the construction of reservoirs by the government

This matter is also supported by the analysis techniques that have been carried out from the beginning of the research discussion, namely synchronic reading, walkthrough analysis, interview data, and cognitive mapping. Concept and arrangement according to general criteria and analysis techniques. Based on the criteria, the concepts and descriptions of the analysis techniques above are carried out:

- Arrange parking areas for vehicles that will use public green open spaces in this area so as not to disturb the primary traffic

- Arrange the road, playground and jogging track in zone 1

- Arranging street furniture and jogging tracks to increase gathering activities in zones 2 and 3

- Arrange the education area by creating pools with new ecosystems and static bikes that create electricity in zone 3
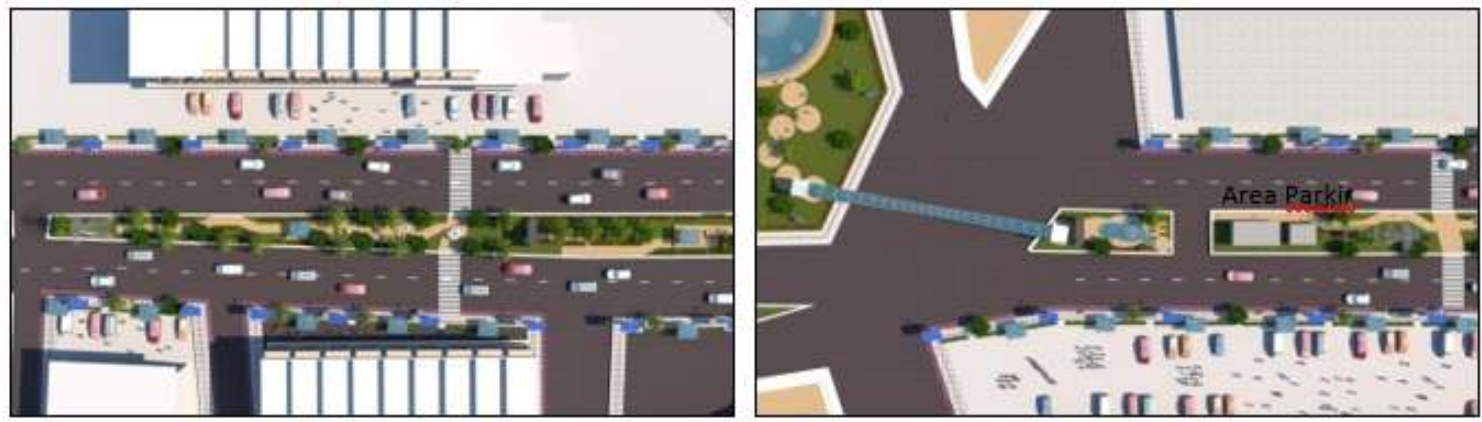

Figure 4.3: Arrangement of Parking Area and Street Furniture in Mayjen Yono Suwoyo Street Corridor

\subsection{The Principle of Providing More Choices}

In this study, the principle of sustainable relations in community life (livability) can be realized in providing more choices such as shelters, walking areas, and cycling, increasing economic competitiveness and supporting communities with recreational, social and environmental opportunities. From the concept above, it adds to the play area and jogging track for recreation, adds seating in the open area, and there are also those who use the shelter for relaxation and add educational areas such as learning the environment with simple tools. The concept of supporting the community can be realized in terms of comfort and human safety in interacting, such as making boundaries and vegetation surrounding the median and road roundabout.

Based on the walkthrough analysis technique, it is known that there are economic activities which are the main activities on Mayjen Yono Suwoyo Street as commercial corridors which become social problems in the saturation and lack of environmental conditions. Based on the criteria, the concepts and descriptions of the above analysis techniques are carried out by arranging road futures, limiting playgrounds, jogging tracks to enhance recreational activities, arranging seating areas with road dividers to gather and organize educational areas by creating ponds with new ecosystems and static bicycles creating electricity.

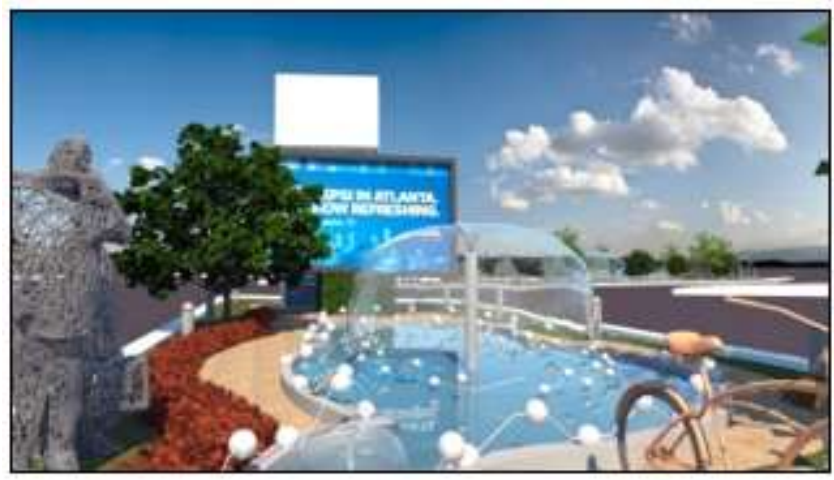

Figure 4.4: Recreation Area Arrangement in Mayjen Yono Suwoyo Street Corridor 


\subsection{Relationship of Interaction between Elements}

In this study, the design characteristics of Mayjen Yono Suwoyo Street Corridor need emphasizing adaptation, repeated and sustained the involvement of humans towards nature, require the integration of designs that are connected with the overall arrangement or space - moreover, foster emotional attachment and interaction in the place. From the concept above, this water reservoir can be improved by making wastewater. As a means to water vegetation in the study area by planting underground pumps and pipes, requiring additional solar energy for electricity - so that additional promotional and lighting areas save more energy and add aesthetic components such as sculpture with gray and beige scrap iron material suitable for commercial corridors. The single directional view amoral technique also supports this matter, and it is known that the vegetation in the median and road roundabout in this area is not optimal so that interactions between humans and nature are also less formed even though this area is sufficient for design integration. Based on the criteria, the concepts and descriptions of the analysis techniques above are carried out:

$>$ Arrange the road roundabout, which is being carried out by increasing the environment as a reservoir. This reservoir can be used as a source for watering plants in the study corridor

$>$ Utilizing solar energy as the primary source of public electricity supply of green open space

$>$ The use of scrap metal material in making sculpture roads with the theme of commercial actors and gray and cream.

$>$ Organize ponds and new ecosystems and provide opportunities for public green open space users to interact with this ecosystem.
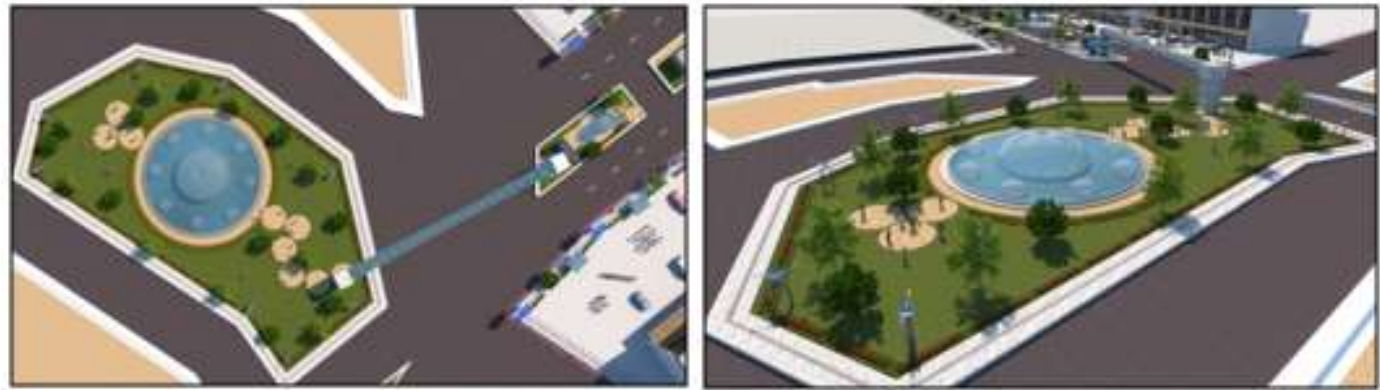

Figure 4.5: Arrangement of the Road Roundabout in Mayjen Yono Suwoyo Street Corridor

In this study, design interaction with nature can be realized by direct interaction, indirect interaction with nature, and the interaction of space and place. From the concept above, it is adding trees in the median and roundabout areas as well as shrubs and ornamental plants such as ferns so that birds can also shelter in the central area and road roundabout. This matter is also supported by a single directional view analysis technique; it is known that along with the Corridor Mayjen Yono Suwoyo has consistent vegetation. Based on the criteria, concepts, and description of the above analysis techniques, it can be done by arranging additional vegetation by allowing road users to interact, such as the use of pavement and ponds.

\section{CONCLUSION}

From the results of the analysis that has been done, it can be formulated and found the factors and sub-factors of research in the sustainable arrangement where social factors that are more focused in this study as a counterweight to economic and environmental activities can synergize in the study area. Structuring social activities in the Corridor of Mayjen Yono Suwoyo is an activity that also supports the environment and economic activities such as relaxation, recreation, and technology. From the synthesis of the literature review, it can be concluded that the research factors are the criteria for public green open space in a sustainable city landscape, the concept of public green open space in urban commercial corridors and sustainable public green space arrangements in commercial corridors. Sustainability can be applied to the study area, namely Mayjen Yono Suwoyo Street Corridor by arranging public green open spaces and elements such as sidewalks and roads based on criteria and concepts in order to increase social, economic, and environmental activities by adding recreation, relaxation, and education to surrounding communities and perpetrators. commercial use the median and road roundabout.

\section{ACKNOWLEDGMENT}

This publication based on Master Program Thesis which conducted in 2019, entitled Reforming Sustainable Green Public Open Space Corridor in Mayjen Yono Suwoyo Street Corridor, Surabaya. 


\section{REFERENCES}

1. Wu, J, “Toward a Landscape Ecology of Cities:Beyond Buildings, Trees, and Urban Forests" Ecology, Planning, and Management of Urban Forests International Perspectives ed. NewYork: Springer Science+Business Media, 2008, pp 1028.

2. Krier, Rob. "Town Spaces. Contemporary Interpretations in Traditional Urbanism” On certain integrals of LipschitzHankel type involving products of Bessel functions. Phil. Trans. Roy. Soc. London, vol. A247, 2003, pp.529-551.

3. Jang, Se Jin, "Sustainable Urban Corridor: Block Pattern and Underutilized Space in Upper King Street District" Charleston, SC, The University Of Charleston, USA, 2014.

4. Black, Thera, "Sustainable Urban Corridors.Northwest Eco Building Guild”, Thurston, 2013.

5. Krier, Rob. “Town Spaces. Contemporary Interpretations in Traditional Urbanism”, Basel/Berlin/Boston, 2003.

6. Romo, Malin, "Public Green Space in Paris : Sustainable Development Discourses in the Objective of Le Grand Paris" Uppsala University, 2015 